\title{
A TECHNICAL EFFICIENCY ANALYSIS OF FINANCIAL SUBSIDIES ALLOCATED BY THE CAP IN ROMANIAN FARMS USING STOCHASTIC FRONTIER ANALYSIS
}

Nicola Galluzzo ${ }^{1}$

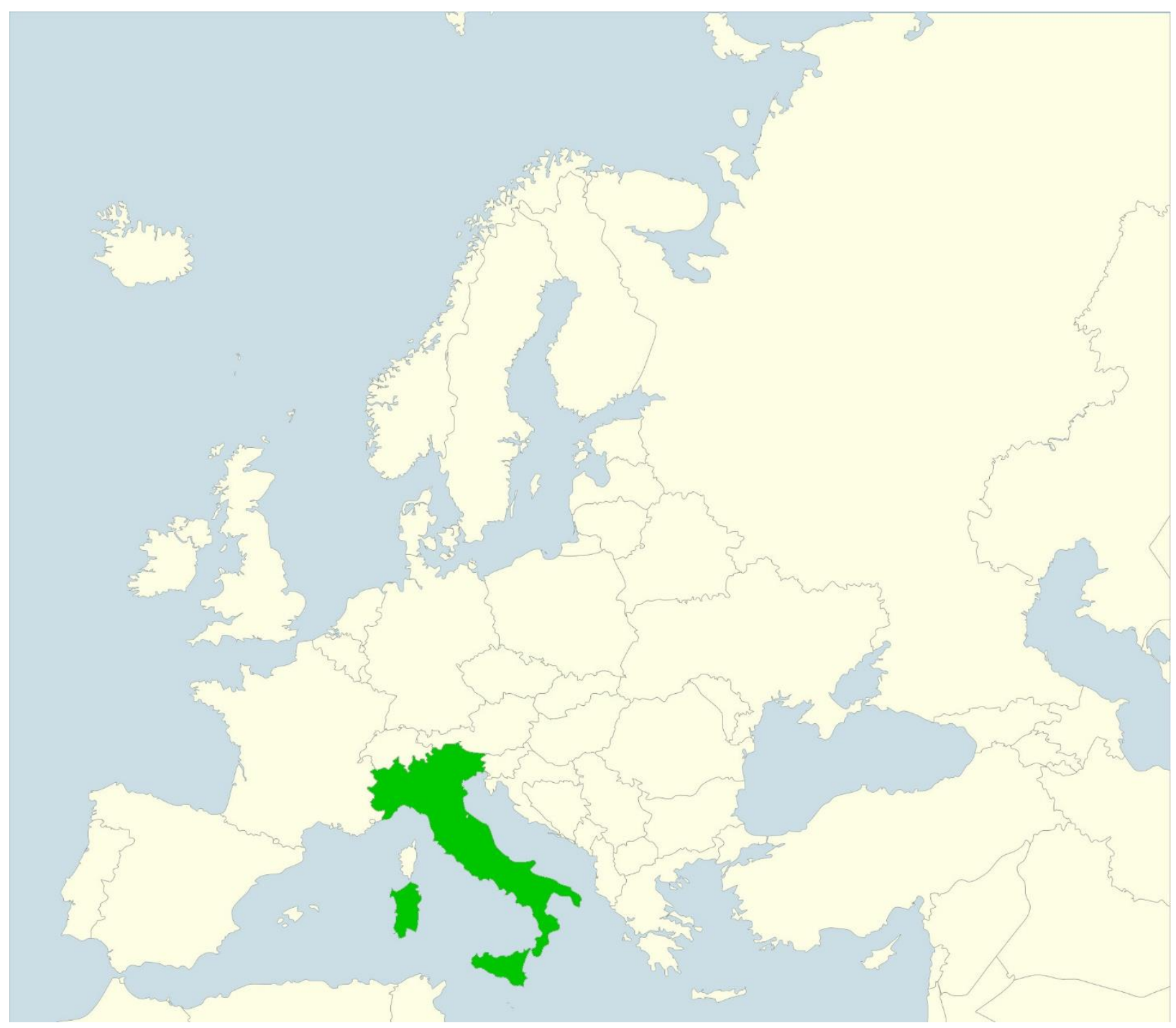

${ }^{1}$ Nicola Galluzzo, ASGEAR Association of Geographical and Economic Studies in Rural Areas, Rieti Italy; email: asgear@libero.it 
Abstract: The Common Agricultural Policy (CAP) has undergone radical changes as a consequence of international agreements. Through a parametric approach based on Stochastic Frontier Analysis, it has been possible to estimate the impact of financial subsidies allocated under the Common Agricultural Policy for the period from 2007 to 2017 in the framework of the first and second pillars to Romanian farms that are part of the FADN dataset. The findings have revealed the positive effect of financial subsidies allocated to disadvantaged rural areas in increasing technical efficiency, and a modest impact of decoupled payments disbursed under the first pillar of the CAP on the Romanian farms investigated.

Keywords: Common Agricultural Policy, Less favoured areas, decoupled payments, rural development, DEA, SFA

Riassunto: La Politica Agricola Comune (PAC) ha subito cambiamenti radicali a seguito degli avvenuti accordi internazionali. Attraverso un approccio parametrico basato sull'analisi della frontiera stocastica, è stato possibile stimare l'impatto dei sussidi finanziari assegnati nell'ambito della Politica Agricola Comune per il periodo 2007-2017 nel quadro del primo e del secondo pilastro per le aziende agricole della Romania facenti parte del campione RICA. I risultati hanno rivelato l'effetto positivo dei sussidi finanziari assegnati alle aree rurali svantaggiate nell'aumentare l'efficienza tecnica e un modesto impatto dei pagamenti disaccoppiati, erogati nell'ambito del primo pilastro della PAC, sulle aziende agricole rumene esaminate.

Parole chiave: politica agricola comune, aree svantaggiate, pagamenti disaccoppiati, sviluppo rurale, DEA, SFA

\section{Introduction}

Over the last 20 years, the Common Agricultural Policy (CAP) has undergone profound changes necessitated by ever more severe budgetary constraints that have radically modified one of the oldest structures of the European Union. In the same time, the accession to the World Trade Organization has implied a radical change in the CAP financial resource allocation. During the seven year time 2007-2013, the major enlargement of the EU in 2004 and in 2007 has implied a different allocation of funds among European States defining different priorities in the economic and financial agenda, which has implied a different provision of funds in order to implement of the convergence among nations, reducing the unemployment and getting the social cohesion better. Since 2014, the CAP has changed its priorities to ensure a greening agriculture, a different allocation of resources from the first to the second pillar, increasing also the technology transfer, the environmental protection (Man \& Ciurea, 2017) and the green innovation to other productive sectors.

At the same time, various international agreements have introduced strict demanding strategies for European farming that have led to a complete overhaul in the allocation of funding by the European Commission to different economic and productive sectors (Beluhova-Uzunova et al., 2017). As a result, according to these authors, the CAP has transitioned from being a commodity-specific policy based on a high level of price support for agricultural produce to being a farmer-specific policy.

Since the dawn of this century, the structure of the CAP has been based on two pillars, each with different and specific targets of action. The first pillar is aimed at indirectly supporting the farmers and their productions, whilst the second pillar is focused on improving living conditions in rural territories through investment in structural and productive infrastructure and on financially supporting the diversification of rural areas, particularly those that are disadvantaged and at risk of severe depopulation and emigration (Galluzzo, 2020). The first pillar of the Common Agricultural Policy, through such instruments as the Single Payment Scheme (SPS), established 
in 2005, and the Single Area Payment Scheme (SAPS) has been pivotal in supporting farmers in all EU Member states directly and in a decoupled way, allocating subsidies and payments completely unrelated to yields. One of the main differences between the two pillars is in the allocation of resources, with the total subsidies paid under the second pillar of the Common Agricultural Policy being significantly lower than those paid under the first pillar (Galluzzo, 2016; 2019a; 2019b; 2020; Stanciu, 2017).

The agriculture in Romania is one of the main economic sectors since the 1900s and lots of people have been employed in the primary sector generating in some counties an agricultural overcrowding (Cartwright, 2001). The recent findings of the National Structural Survey in Agriculture, carried out by the Romanian Institute of Statistics, and also other statistical data published by Eurostat have pointed out a significant prevalence of small farms managed by aged farmers, with a modest level of land capital close to 3.6 hectares far below of the EU average equal to 16 hectares (Vasile et al., 2017). According the European Union, more than $23 \%$ of Romanian people work in agriculture and farmers with a full agricultural training are $0.4 \%$ of all farm manager twenty times lower than the average value assessed in all EU countries. The poor size of land capital, the aging of farmers compared to other European countries, do not ensure an optimal and technical efficiently use of input and labour saving investments with the consequence to reduce the technical efficiency in Romanian farms (Anghelache, 2018; Bularca \& Toma, 2018). The main consequence for Romanian farms is a lower competitiveness than the other EU member states farms (Ciutacu et al., 2015; Feher et al., 2017). The poor land capital endowment in Romanian farms has implied a very modest gross value added in agriculture, a low output and a limited level of financial subsidies allocated by the first and second pillar of the CAP. Hence, the technical efficiency in farms is lower than other EU farms (Turnock, 2016). Recent studies in all European countries, which have investigated the technical efficiency by the non-parametric approach, have pointed out that Romania has had the lowest level of technical efficiency (Novak et al., 2015) and in literature, there is a clear predominance of nonparametric methods to parametric ones. This research has filled the gap in Romanian literature about the technical efficiency assessment using the parametric approach to assess the technical efficiency both in different type of farming and also during the time.

\section{A literature review on technical efficiency and CAP subsidies}

In order to estimate the productivity of farms, it is possible to use a simple ratio between output value and input value (Osman \& Anouze, 2014) and, thus, technical efficiency as the ability of an enterprise to obtain an optimal output using a given input (Farrell, 1957; Coelli et al., 2005). In general, the main elements in estimating the technical efficiency of farms and in assessing the impact of financial subsidies allocated under the Common Agricultural Policy, are related to the dimension of farms, their level of income, and their degree of socio-economic sustainability (Galluzzo, 2013; Latruffe et al., 2016; Latruffe et al., 2017; Minviel \& Latruffe, 2017). Decoupled payments act predominately on the level of income through the dimension of farms, and consequently, this has encouraged a growing demand for land capital endowment (Bartolini \& Viaggi, 2013). In relation to other European countries, studies have revealed either a null or fairly minimal impact of payments allocated under the second pillar to disadvantaged rural areas (Barath et al., 2017; 2020; Nowak et al., 2015; Rudinskaya et al., 2019; Garrone et al., 2019) and it is difficult to find a univocal interpretation assessing the correlation between increased efficiency, public financial support for agriculture, and employment opportunities (Petrick \& Zier, 2011; Galluzzo, 2019a).

A wide review of the literature has revealed many studies that have investigated, in depth through a quantitative approach, the financial subsidies allocated under the Common Agricultural Policy to farms in different European countries and their impact in terms of reducing imbalances between farms and territories (Garrone et al., 2019; Minviel \& Latruffe, 2017; Galluzzo, 2016; Mishra et al., 2009). Furthermore, as financial support allocated under the Common Agricultural Policy has reduced, the need for farmers to improve their economic and technical efficiency has risen, even if the effect of decoupled payments on the farm's technical efficiency is ambiguous in function of the farm's productive specialisation, the type of subsidy (decoupled or otherwise) and, in many 
cases, have distorted effects on farmers' technical efficiency and productivity (Mennig \& Sauer, 2019; Garrone et al., 2019; Latruffe et al., 2017; Galluzzo, 2016; 2019a; Nowak et al., 2015; Swinbank, 2008; Zhu \& Lansink, 2010; Rude, 2008; Ciaian \& Swinnen, 2006; Ciaian et al., 2014; Rizov et al., 2013).

One of the main consequences of the MacSharry reforms in the early 1990s, and of the Agenda 2000 programme, has been the impact of direct payments allocated under the first pillar of the Common Agricultural Policy on the farmer's net income and on the income distribution of farms (Keeney, 2000; Galluzzo, 2016). Von Witze and Noleppa (2007) have argued that direct payments made to German farms have had an unequal impact, particularly in regards to some smaller sized farms, with a clear and fairly pronounced favouring of disadvantaged rural areas. In contrast, other studies focusing on the new member states of the European Union have found a null or negative impact of subsidies allocated under the CAP on the general level of technical efficiency, particularly in the case of farms located in mountainous and disadvantaged rural areas (Rudinskaya et al., 2019; Barath et al., 2017; Galluzzo, 2016; 2019a). Other research studies have underlined a significant but modest nexus between financial support provided by the Common Agricultural Policy and the development of rural areas (Shucksmith et al., 2005; Crescenzi \& Rodriguez-Pose, 2011; Galluzzo, 2016; 2019a).

In 2010 and 2012, Zhu and Lansik and Zhu and Milán Demeter, respectively, investigated the effect of subsidies allocated under the CAP to arable and dairy farms in different EU countries, and found them to have been positive in the case of specialised milk farms and ambiguous in the case of crop farms. In both France and Spain, agri-environment payments have had a positive impact, playing a fundamental role in driving farmer's choices and driving the conversion of farms from a conventional system of production to an organic one (Picazo-Tadeo et al., 2011; Latruffe \& Nauges, 2014) and leading to increases in both productivity and technical efficiency (Mennig \& Sauer, 2019). Studies by Latruffe and Desjeux in 2016 and Latruffe et al. in 2017 investigated the impact on technical efficiency of decoupled payments and other financial support allocated through the framework of the second pillar of the CAP in France and other various European countries. These authors found a generally negative effect of investment subsidies on technical efficiency in farms specialising in beef production, but a generally positive effect of production subsidies on farms specialising in field crops and dairy. In contrast, they found rural development subsidies such as Less Favoured Areas (LFA) payments and agri-environmental payments schemes had had no discernible effect on technical efficiency. Meanwhile, studies focused on new member states of the European Union have demonstrated the fundamental role that subsidies allocated under the second pillar of the CAP have had, even if findings show that LFA subsides have had no impact in the case of Slovenian farms (Barath et al., 2017).

\section{Aim of the research}

The aim of this research was to assess the level of technical efficiency in Romanian farms over the period from 2007 to 2017 through a parametric approach such as the Stochastic Frontier Analysis. Attention is focused on estimating the impact of financial subsidies in the form of decoupled payments allocated under the first pillar and of payments to disadvantaged rural areas (LFA payments) in the framework of the second pillar of the CAP on technical efficiency in a sample of Romanian farms that are included in the Farm Accountancy Data Network (FADN). Another core purpose of the study was to assess changes in technical efficiency over the period of investigation, comparing data of different types of farming represented in the sample of Romanian farms.

\section{Methodology}

In order to make an in-depth estimation of technical efficiency it is possible to follow two different approaches: One is a parametric approach, called Stochastic Frontier Analysis (SFA), while the other is a non-parametric approach, namely Data Envelopment Analysis or DEA (Charnes et al., 1978; Banker et al., 1984; Kumbhakar et al., 2015; Cooper et al., 2007; Farrell, 1957; Lovell, 1993; Coelli et al., 2005; Battese \& Coelli, 1992; 1995; Galluzzo, 2019b). 
The assessment of technical efficiency by the stochastic production frontier model was first proposed in 1977 by Aigner et al. and by Meeusen and Van Den Broeck (Battese \& Coelli, 1995). In a parametric approach using stochastic frontier analysis, one needs a specific and well-defined production function such as the Cobb-Douglas, Translog, or other type of function, as well as other a priori specifications in a deterministic framework (Coelli et al., 2005; Lovell, 1993). Furthermore, the SFA does not allow the technical efficiency to be estimated using multiple outputs and the estimation of the function, and the model is not sensitive to outlier data (Coelli et al., 2005; Kumbhakar et al., 2015; Aigner et al., 1977; Meeusen and Van Den Broeck, 1977). The optimal level of efficiency is represented by all the enterprises located on the frontier of technical efficiency. In contrast, enterprises found below this frontier can be considered inefficient. The technical inefficiency is representative of two components, one based on the random error and another based on technical inefficiency (Battese \& Coelli, 1995; Kumbhakar et al., 2015; Aigner et al., 1977; Meeusen and Van Den Broeck, 1977).

A brief bibliographical review analysing technical efficiency in farms conducted by Bravo-Ureta et al. in 2007 investigated a total of 579 studies published between 1979 and 2005. Of these, 482 studies employed a parametric approach (SFA) while only 87 used a non-parametric approach (DEA). Focusing on the field of investigation, findings reveal that herbaceous crops (rice, wheat, corn) and livestock (cows and sheep) have been the main topics of study of technical efficiency in agriculture predominately carried out in the USA, in different European Union states, India, Australia, and in the Philippines.

Summing up the comparison between SFA and DEA, it emerges that stochastic frontier analysis requires the definition of a specific function and other assumptions, but it is able to assess the inefficiency as the sum of noise errors, which the DEA approach does not estimate, and the component of inefficiency (Ruggiero, 2007; Cooper et al., 2007; Coelli et al., 2005; Emrouznejad \& Cabanda, 2014); hence, the assessment of the technical efficiency function is based on a stochastic frontier estimated by a regression in which the unobserved error component is made up by inefficiency and statistical noise which is not under the control of the entrepreneur (Ruggiero, 2007; Madau, 2007).

In this research, we have analysed the data of a sample of Romanian farms that are included in the FADN Farm Accountancy Data Network during the period from 2007 to 2017, adopting a methodology that employs input oriented stochastic analysis based on a panel data investigating changes in the technical efficiency of farms of different typologies over the period, as well as meta-frontier analysis to highlight the main changes in all investigated types of farming, in order to compare changes in the technical efficiency of farms, estimated for every year of investigation and for all types of farming. The estimation has been carried out using FRONTIER software.

Battese and Coelli in 1995 proposed an estimation of technical efficiency in a stochastic frontier function in a panel data set (Mennig \& Sauer, 2019; Aigner et al., 1977; Meeusen and Van Den Broeck, 1977) as:

$Y_{i t}=\exp \left(x_{i t} \beta+V_{i t}+U_{i t}\right)$

where $Y_{i t}$ is the output produced by a specific function of production in $t_{\text {th }}$ observation $(t=1,2$, $3, \ldots N)$ in $i_{\text {-th }}$ enterprises $(i=1,2,3, \ldots N) ; X_{i t}$ are the different inputs in each enterprise over the time; $\beta$ is a vector of parameters to estimate because they are unknown; $V_{\text {it }}$ are random errors i.i.d. of the $\bigcup_{i t}$ as a normal function, with average zero and standard deviation $\sigma^{2}$; $\bigcup_{i t}$ are random variables associated to the technical inefficiency, assumed to be identically distributed with average $z_{i t} \delta$ and variance $\sigma^{2} ; z_{i t}$ is a vector of explanatory variables linked to the technical inefficiency of each enterprise over the period of investigation; and $\delta$ is a vector of unknown coefficients.

In order to assess the technical inefficiency effect in this paper, the study had applied the mathematical expression: 
where Wit is the random variable defined by the truncation of the normal distribution function with mean zero and variance $\sigma^{2}$ (Battese \& Coelli, 1995).

Following these two authors (Battese \& Coelli, 1995), it is possible to estimate the technical efficiency (TE) in a function of production using the equation:

$\mathrm{TE}_{\mathrm{it}}=\exp \left(-\mathrm{U}_{\mathrm{it}}\right)=\exp \left(-\mathrm{z}_{\mathrm{it}} \mathrm{\delta}-\mathrm{W}_{\mathrm{it}}\right)$

Summing up, in the SFA approach the random error $\left(\mathrm{V}_{\mathrm{it}}\right)$ is distributed in a symmetrical way and is assumed to be independently and identically distributed as a normal $N\left(0, \sigma^{2}\right), U_{\text {it }}$ is able to explain the technical inefficiency as an independently and identically distributed function as a truncation, and the parameters of the equation can be calculated using Maximum Likelihood Estimation (Mennig \& Sauer, 2019; Aigner et al., 1977; Meeusen and Van Den Broeck, 1977). The variance is expressed as the sum of the variance of the random error $\left(\mathrm{V}_{\mathrm{it}}\right)$ and the variance of the technical inefficiency $\left(\mathrm{U}_{\mathrm{it}}\right)$, and the ratio between these two variances $(\mathrm{V})$ is between 0 and 1. In this research, the parameters in the model of technical efficiency have been estimated simultaneously in order to reduce the bias, which is the negative aspect of an assessment using a two-step approach (Wang \& Schmidt, 2002; Manevska-Tasevska et al., 2016; Madau, 2007).

The data source is the European Farm Accountancy Data Network during the period 2007 to 2017 for all Romanian regions and in all eight types of farming identified by EU Regulation 1242 published in 2008, namely: field crops, horticulture, wine, other permanent crops, dairy, other grazing farms, granivores, and mixed farms. The output variable used in this paper was the total output produced by farms. The input variables were: labour, measured in terms of hours per farm per year; land capital expressed as usable agricultural area in hectares; specific costs of fertilisers, seeds and plants, and pesticides; total farming overhead costs or, rather. supply costs linked to the production activity but not linked to specific lines of production; total assets in terms of fixed and current assets in ownership of the farm; subsidies paid to disadvantaged rural areas (LFA payments) allocated under the second pillar of the CAP; and decoupled payments allocated to farms within the framework of the first pillar of the CAP, comprising single farm payments and single area payments, as well as additional support.

Tab 1. Meta-frontier findings in the Maximum Likelihood Estimation (MLE) estimated in all type of farming and in all Romanian counties since 2007 to 2017. The coefficient are the estimated elasticities of output to all investigated input. Source: author's elaboration on data https://ec.europa.eu/agriculture/rica/database/database_en.cfm

\begin{tabular}{|l|c|c|c|}
\hline \multicolumn{1}{|c|}{ Variable } & Coefficient & St. error & t-ratio \\
\hline Constant & 0.79 & 0.63 & 1.23 \\
\hline Labour & 0.073 & 0.072 & 1.01 \\
\hline Usable Agricultural Areas (UAA) & 0.13 & 0.053 & $2.60^{\star *}$ \\
\hline Specific costs & 0.48 & 0.042 & $12.05^{\star \star *}$ \\
\hline Total farming overhead costs & 0.23 & 0.08 & $2.94^{\star *}$ \\
\hline Assets & 0.27 & 0.051 & $5.29^{\star \star \star}$ \\
\hline LFA payments & -0.097 & 0.038 & $-2.54^{\star *}$ \\
\hline Decoupled payments & 0.009 & 0.011 & 0.78 \\
\hline Gamma & 0.711 & & \\
\hline Log likelihood function & 47.13 & & \\
\hline LR test & 16.17 & & \\
\hline
\end{tabular}

** ${ }^{* * *}$ stands respectively for significance at $0.01-0.05$ and lower 0.01 


\section{Results and Discussion}

The analysis of panel data from 2007 to 2017 across all types of farming and in all Romanian counties has revealed that the half-normal function is adequate to the model, and a value of gamma close to 0.71 explains more than $70 \%$ of the composite error is due to the inefficient term.

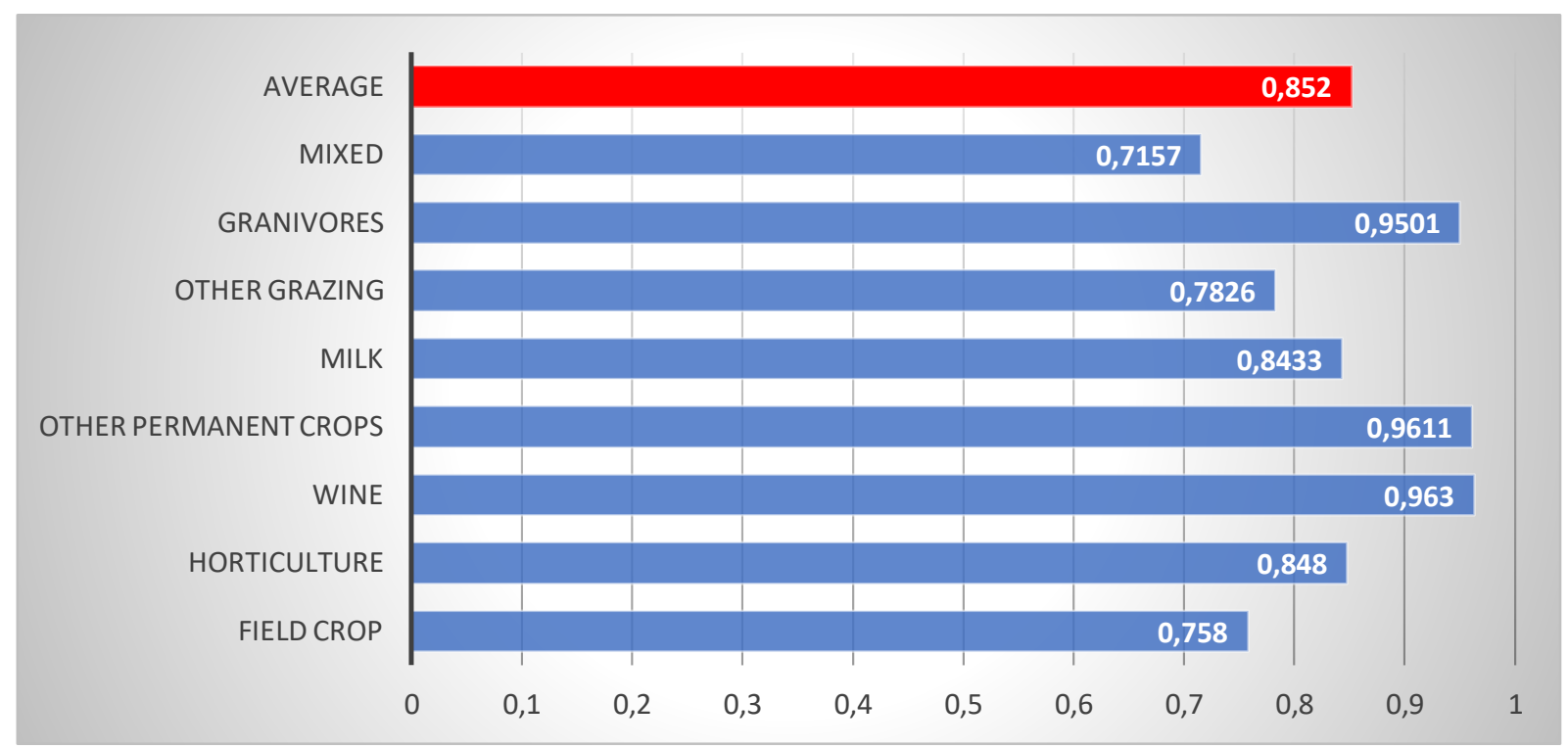

Fig 1. Meta-frontier analysis of technical efficiency assessed in all type of farming in Romanian farms part of FADN dataset since 2007 to 2017. Source: author's elaboration on data https://ec.europa.eu/agriculture/rica/database/database_en.cfm

The findings in the meta-frontier analysis by the final estimation in the maximum likelihood model (MLE) show that the input variables usable agricultural area, specific costs, total farming overhead costs, total assets, and LFA subsidies are all statistically significant in the model while, in contrast, decoupled payments have no discernible effects on the model (Tab. 1). The value of Gamma in table 1 , made by the ratio of variance of the inefficiency on the total variance in the model has been able to explain as more than 0.71 of the total variance is due to the inefficiency component. The coefficients are able to explain the elasticity of output to each input. The sum of production elasticities estimated in all inputs in the model have been above 1, implying increasing returns to scale, hence an increase in input would lead to an increase in total output.

Tab 2. Technical efficiency in input-oriented model assessed in different type of farming since 2007 to 2017. Source: author's elaboration on data https://ec.europa.eu/agriculture/rica/database/database_en.cfm

\begin{tabular}{|l|l|l|l|l|l|l|l|l|l|l|l|c|}
\hline $\begin{array}{l}\text { Type of } \\
\text { farming } \\
\text { (TF) }\end{array}$ & $\begin{array}{l}\mathbf{2 0 0} \\
\mathbf{7}\end{array}$ & $\begin{array}{l}\mathbf{2 0 0} \\
\mathbf{8}\end{array}$ & $\begin{array}{l}\mathbf{2 0 0} \\
\mathbf{9}\end{array}$ & $\begin{array}{l}\mathbf{2 0 1} \\
\mathbf{0}\end{array}$ & $\begin{array}{l}\mathbf{2 0 1} \\
\mathbf{1}\end{array}$ & $\begin{array}{l}\mathbf{2 0 1} \\
\mathbf{2}\end{array}$ & $\begin{array}{l}\mathbf{2 0 1} \\
\mathbf{3}\end{array}$ & $\begin{array}{l}\mathbf{2 0 1} \\
\mathbf{4}\end{array}$ & $\begin{array}{l}\mathbf{2 0 1} \\
\mathbf{5}\end{array}$ & $\begin{array}{l}\mathbf{2 0 1} \\
\mathbf{6}\end{array}$ & $\begin{array}{l}\mathbf{2 0 1} \\
\mathbf{7}\end{array}$ & $\begin{array}{l}\text { Averag } \\
\text { e per TF }\end{array}$ \\
\hline Field crop & 0.92 & 0.90 & 0.89 & 0.88 & 0.87 & 0.85 & 0.83 & 0.81 & 0.79 & 0.76 & 0.74 & 0.84 \\
\hline $\begin{array}{l}\text { Horticultur } \\
\text { e }\end{array}$ & 0.90 & 0.89 & 0.87 & 0.86 & 0.84 & 0.82 & 0.80 & 0.77 & 0.75 & 0.72 & 0.69 & 0.81 \\
\hline Wine & 0.94 & 0.93 & 0.92 & 0.91 & 0.90 & 0.89 & 0.88 & 0.86 & 0.84 & 0.83 & 0.80 & 0.88 \\
\hline $\begin{array}{l}\text { Other } \\
\text { permanent } \\
\text { crops }\end{array}$ & 0.97 & 0.97 & 0.96 & 0.95 & 0.95 & 0.94 & 0.93 & 0.93 & 0.92 & 0.91 & 0.90 & 0.93 \\
\hline Milk & 0.91 & 0.89 & 0.88 & 0.87 & 0.85 & 0.83 & 0.81 & 0.79 & 0.76 & 0.74 & 0.71 & 0.82 \\
\hline $\begin{array}{l}\text { Other } \\
\text { grazing }\end{array}$ & 0.87 & 0.85 & 0.83 & 0.81 & 0.79 & 0.77 & 0.74 & 0.71 & 0.68 & 0.65 & 0.61 & 0.75 \\
\hline Granivores & 0.92 & 0.91 & 0.90 & 0.89 & 0.87 & 0.86 & 0.84 & 0.82 & 0.80 & 0.78 & 0.75 & 0.84 \\
\hline Mixed & 0.86 & 0.84 & 0.82 & 0.80 & 0.77 & 0.75 & 0.72 & 0.69 & 0.65 & 0.62 & 0.58 & 0.73 \\
\hline $\begin{array}{l}\text { Average } \\
\text { per year }\end{array}$ & 0.91 & 0.90 & 0.88 & 0.87 & 0.86 & 0.84 & 0.82 & 0.80 & 0.77 & 0.75 & 0.72 & - \\
\hline
\end{tabular}


Tab 3. Main findings in the MLE estimates in all Romanian regions investigated since 2007 to 2017. Source: author's elaboration on data https://ec.europa.eu/agriculture/rica/database/database_en.cfm

\begin{tabular}{|l|c|c|c|}
\hline Variable & Coefficient & St. error & t-ratio \\
\hline Constant & -0.10 & 0.85 & 1.18 \\
\hline Labour & 0.34 & 0.12 & $2.81^{* *}$ \\
\hline Usable Agricultural Areas (UAA) & 0.10 & 0.044 & $2.39^{\star *}$ \\
\hline Specific costs & 0.50 & 0.041 & $12.22^{* * *}$ \\
\hline Total farming overhead costs & 0.16 & 0.075 & $2.17^{* *}$ \\
\hline Assets & 0.26 & 0.051 & $5.12^{\star * \star}$ \\
\hline LFA payments & -0.087 & 0.031 & $2.75^{* *}$ \\
\hline Decoupled payments & 0.064 & 0.012 & 0.52 \\
\hline Sigma square & 0.032 & 0.0113 & $2.86^{* *}$ \\
\hline Gamma & 0.52 & 0.17 & $2.97^{* *}$ \\
\hline Mu & 0.26 & 0.13 & $1.93^{*}$ \\
\hline eta & -0.12 & 0.045 & $2.81^{* *}$ \\
\hline Log likelihood function & 50.96 & & \\
\hline LR test & 23.85 & & \\
\hline
\end{tabular}

${ }^{*},{ }^{* *},{ }^{* * *}$ stands respectively for significance at $0.10-0.05,0.05-0.01$ and lower 0.01

The findings assessed in the panel data have revealed that, in all Romanian regions over the period of investigation, the input variables labour, usable agricultural areas, specific costs correlated to the crops and grazing, total farm overhead costs, assets, and LFA subsidies to disadvantaged rural areas, have had a significant correlation to the total output (Tab. 3). Comparing table 1 to table 3 , it is possible to observe the input labour has been statistically significant in Romanian regions hence, there are different technical efficiency allocation of the labour than type of farming and consequently, crop specialization and some changes in this input can act directly on technical efficiency of farms. In stark contrast, decoupled payments do not seem to have had any effect on the total output. The estimation by the log likelihood function has underlined that there are some inefficiency effects in the function with a half-normal distribution. This is corroborated by the value of the mu, which is close to 0.93 , hence, we can accept the null hypothesis and the half-normal is adequate to this model of estimation. The sigma squared $\left(\sigma^{2}\right)$ has been found to be significant, hence the variance of the inefficiency component is significant and, also the gamma is able to explain more than $52 \%$ of the composite error as due to the inefficient terms.

\section{Conclusions}

Drawing some conclusions, this research has revealed a significant fluctuation in technical efficiency over the period of study due to some meaningful changes in the transition phase of the Common Agricultural Policy during the last two seven-year periods. The findings have highlighted that a farm's specialisation represents a key element in increasing its level of technical efficiency and, hence, demonstrated the need for farmers to specialise in crops that are able to adequately remunerate the investments of land capital as well as labour input.

Some of the most critical factors affecting Romanian farming, in fact, is the generally modest level of land capital, which has devastating consequences on farms' ability to specialise, as well as the limited availability of capital investment for new labour-saving technologies, which would enable farms to reduce their excessive demand for labour input.

Farms located in lagging-behind rural areas have clearly benefited from the allocation of financial subsidies specifically aimed at reducing the socio-economic marginalisation of rural territories. This implies the need, during the next seven-year period from 2021-2027, for the European Union and local public administrations to take a courageous approach to support the second pillar of the CAP in order to encourage diversification and generational turnover in the rural space, adequately supporting the small farming enterprises located in scattered villages that represent the tools able to counter critical socio-economic aspects that, unchecked, lead to permanent emigration and the risk of rural marginalisation. 
[1] Aigner, D., Lovell, C. K. \& Schmidt, P. (1977). Formulation and estimation of stochastic frontier production function models. Journal of econometrics6(1), 21-37. DOI: 10.1016/0304-4076(77)90052-5.

[2] Anghelache, C. (2018). Structural analysis of Romanian agriculture. Romanian Statistical Review Supplement 66(2), 11-18.

[3] Banker, R. D., Charnes, A. \& Cooper, W. W. (1984). Some models for estimating technical and scale inefficiencies in data envelopment analysis. Management Science 30(9), 10781092. DOI: $10.1287 / \mathrm{mnsc} .30 .9 .1078$.

[4] Baráth, L., Fertő, I. \& Bojnec, Š. (2018). Are farms in less favored areas less efficient? Agricultural Economics, 49(1), 3-12. DOI: 10.1111/agec.12391.

[5] Bartolini, F. \& Viaggi, D. (2013). The common agricultural policy and the determinants of changes in EU farm size. Land Use Policy, 31, 126-135. DOI: 10.1016/j.landusepol.2011.10.007.

[6] Battese, G. E. \& Coelli, T. J. (1992). Frontier production functions, technical efficiency and panel data: with application to paddy farmers in India. Journal of Productivity Analysis, 3(12), 153-169. DOI: 10.1007/978-94-017-1923-0_10.

[7] Battese, G. E. \& Coelli, T. J. (1995). A model for technical inefficiency effects in a stochastic frontier production function for panel data. Empirical Economics 20(2), 325-332. DOI: $10.1007 / B F 01205442$.

[8] Beluhova-Uzunova, R., Atanasov, D. \& Hristov, K. (2017). Analysis of direct payments distribution in Bulgarian agriculture. Trakia Journal of Sciences, 15(1), 282-287. DOI: 10.15547/tjs.2017.s.01.051.

[9] Bravo-Ureta, B. E., Solís, D., Moreira López, V. H., Maripani, J. F., Thiam, A. \& Rivas, T. (2007). Technical efficiency in farming: a meta-regression analysis. Journal Productivity Analysis, 27, 57-72. DOI: 10.1007/s11123-006-0025-3.

[10] Bularca, E. \& Toma, E. (2018). Structural change in the Romanian agriculture: implications for the farming sector. Scientific Papers Series-Management, Economic Engineering in Agriculture and Rural Development, 18(2), 59-66.

[11] Cartwright, A. L. (2001). The return of the peasant. Land reform in post-communist Romania. New York: Routledge. DOI: 10.4324/9781315187341.

[12] Charnes, A., Cooper, W. W. \& Rhodes, E. (1978). Measuring the efficiency of decision making units. European Journal of Operational Research 2, 429-444. DOI: 10.1016/03772217(79)90229-7.

[13] Ciaian, P. \& Swinnen, J. F. (2006). Land market imperfections and agricultural policy impacts in the new EU member states: a partial equilibrium analysis. American Journal of Agricultural Economics 88(4), 799-815. DOI: 10.1111/j.1467-8276.2006.00899.x.

[14] Ciaian, P., Kancs, D. A. \& Swinnen, J. (2014). The impact of the 2013 reform of the common agricultural policy on land capitalization in the European Union. Applied Economic Perspectives and Policy 36(4), 643-673. DOI: 10.1093/aepp/ppu016.

[15] Ciutacu, C., Chivu, L. \& Andrei, J. V. (2015). Similarities and dissimilarities between the EU agricultural and rural development model and Romanian agriculture. Challenges and perspectives. Land Use Policy 44, 169-176. DOI: 10.1016/ j.landusepol.2014.08.009.

[16] Coelli, T. J., Rao, D. S. P., O'Donnell, C. J. \& Battese, G. E. (2005). An introduction to efficiency and productivity analysis. Berlin: Springer Verlag. DOI: 10.1007/978-1-46155493-6. 
[17] Cooper, W. W., Seiford, L. M., Tone, K. \& Zhu, J. (2007). Some models and measures for evaluating performances with DEA: past accomplishments and future prospects. Journal of Productivity Analysis, 28(3), 151-163. DOI: 10.1007/s11123-007-0056-4.

[18] Crescenzi, R. \& Rodríguez-Pose, A. (2011). Reconciling top-down and bottom-up development policies. Environment and Planning A, 43(4), 773-780.

[19] Emrouznejad, A. \& Cabanda, E. (2014). Introduction to data envelopment analysis and its applications. In Osman, I. H, Anouze, A. L. \& Emrouznejad, A., eds. Handbook of research on strategic performance management and measurement using data envelopment analysis (pp. 235-255). Hershey: IGI Global.

[20] Farrell, M. J. (1957). The measurement of productive efficiency. Journal of the Royal Statistical Society: Series A (General), 120(3), 253-281. DOI: 10.2307/2343100.

[21] Feher, A., Goșa, V., Raicov, M., Haranguș, D. \& Condea, B. V. (2017). Convergence of Romanian and Europe Union agriculture-evolution and prospective assessment. Land Use Policy 67, 670-678. DOI: 10.1016/ j.landusepol.2017.06.016.

[22] Galluzzo, N. (2013). Farm dimension and efficiency in Italian agriculture: a quantitative approach. American Journal of Rural Development 1(2), 26-32.

[23] Galluzzo, N. (2016). An analysis of the efficiency in a sample of small Italian farms part of the FADN dataset. Agricultural Economics 62(2), 62-70. DOI: 10.17221/37/2015AGRICECON.

[24] Galluzzo, N. (2019a). A long-term analysis of the Common Agricultural Policy financial subsidies towards Italian farms. Ukranian Journal on Veterinary and Agricultural Science, 2(1), 12-17. DOI: 10.32718/ujvas2-1.03.

[25] Galluzzo, N. (2019b). An analysis of technical efficiency in Icelandic dairy and sheep farms. Studies in Agricultural Economics 121(3), 144-150.

[26] Galluzzo, N. (2020). Analysis of resilience in Romanian rural farm areas by a quantitative approach. Bulgarian Journal of Agricultural Science 26(1), 16-22.

[27] Garrone, M., Emmers, D., Lee, H., Olper, A. \& Swinnen, J. (2019). Subsidies and agricultural productivity in the EU. Agricultural Economics 50(6), 803-817. DOI: 10.1111/agec.12526.

[28] Keeney, M. (2000). The distributional impact of direct payments on Irish farm incomes. Journal of Agricultural Economics 51, 252-265. DOI: 10.1111/j.1477-9552.2000.tb01227.x.

[29] Kumbhakar, S. C., Wang, H. J. \& Horncastle, A. P. (2015). A practitioner's guide to stochastic frontier analysis using Stata. Cambridge: Cambridge University Press. DOI: $10.1017 /$ CBO9781139342070.

[30] Latruffe, L. \& Desjeux, Y. (2016). Common Agricultural Policy support, technical efficiency and productivity change in French agriculture. Review of Agricultural, Food and Environmental Studies 97(1), 15-28. DOI: 10.1007/s41130-016-0007-4.

[31] Latruffe, L. \& Nauges, C. (2014). Technical efficiency and conversion to organic farming: the case of France. European Review of Agricultural Economics 41(2), 227-253. DOI: 10.1093/erae/jbt024.

[32] Latruffe, L., Bravo-Ureta, B. E., Carpentier, A., Desjeux, Y. \& Moreira, V. H. (2017). Subsidies and technical efficiency in agriculture: Evidence from European dairy farms. American Journal of Agricultural Economics 99(3), 783-799. DOI: 10.1093/ajae/aaw077.

[33] Latruffe, L., Diazabakana, A., Bockstaller, C., Desjeux, Y., Finn, J., Kelly, E., Ryan, M. \& Uthes, S. (2016). Measurement of sustainability in agriculture: a review of indicators. Studies in Agricultural Economics 118(3), 123-130. DOI: 10.7896/j.1624.

[34] Lovell, C. K. (1993). Production frontiers and productive efficiency. In Fried, H. O., Schmidt, S. S., eds., The measurement of productive efficiency: Techniques and applications (pp. 367). Oxford University Press. 
[35] Madau, F. A. (2007). Technical efficiency in organic and conventional farming: Evidence from Italian cereal farms. Agricultural Economics Review, 8(1), 5-21.

[36] Man, M. \& Ciurea, M. (2017). Considerations on the Common Agricultural Policy in Romanian Agriculture. Ovidius University Annals, Economic Sciences Series 17(2), 243-248.

[37] Manevska-Tasevska, G., Rabinowicz, E. \& Surry, Y. (2016). Pure and compensated efficiency of Swedish dairy farms. Agricultural and Food Science 25(2), 111-123. DOI: 10.23986/afsci.53182.

[38] Meeusen, W. \& van Den Broeck, J. (1977). Efficiency estimation from Cobb-Douglas production functions with composed error. International Economic Review 18(2), 435-444. DOI: $10.2307 / 2525757$.

[39] Mennig, P. \& Sauer, J. (2019). The impact of agri-environment schemes on farm productivity: a DID-matching approach. European Review of Agricultural Economics 47(3), 1045-1093. DOI: 10.1093/erae/jbz006.

[40] Minviel, J. J. \& Latruffe, L. (2017). Effect of public subsidies on farm technical efficiency: a meta-analysis of empirical results. Applied Economics 49(2), 213-226. DOI: 10.1080/00036846.2016.1194963.

[41] Mishra, A., El-Osta, H. \& Gillespie, J. M. (2009). Effect of agricultural policy on regional income inequality among farm households. Journal of Policy Modeling, 31(3), 325-340. DOI: 10.1016/j.jpolmod.2008.12.007.

[42] Nowak, A., Kijek, T. \& Domańska, K. (2015). Technical efficiency and its determinants in the European Union. Agricultural Economics 61(6), 275-283. DOI: 10.17221/200/2014AGRICECON.

[43] Osman, I. H. \& Anouze, A. L. (2014). A cognitive analytics management framework (CAMPart 3): Critical skills shortage, higher education trends, education value chain framework, government strategy. In Osman, I. H, Anouze, A. L. \& Emrouznejad, A., eds, Handbook of research on strategic performance management and measurement using data envelopment analysis (pp. 190-234). Hershey: IGI Global.

[44] Petrick, M. \& Zier, P. (2011). Regional employment impacts of Common Agricultural Policy measures in Eastern Germany: a difference-in-differences approach. Agricultural Economics, 42(2), 183-193. DOI: 10.1111/j.1574-0862.2010.00509.x.

[45] Picazo-Tadeo, A. J., Gómez-Limón, J. A. \& Reig-Martínez, E. (2011). Assessing farming ecoefficiency: a data envelopment analysis approach. Journal of Environmental Management 92(4), 1154-1164. DOI: 10.1016/j.jenvman.2010.11.025.

[46] Rizov, M., Pokrivcak, J. \& Ciaian, P. (2013). CAP subsidies and productivity of the EU farms. Journal of Agricultural Economics 64(3), 537-557. DOI: 10.1111/1477-9552.12030.

[47] Rude, J. (2008). Production effects of the European Union's single farm payment. Canadian. Journal of Agricultural Economics / Revue Canadienne d'Agroeconomie, 56(4), 457-471. DOI: 10.1111/j.1744-7976.2008.00141.x.

[48] Rudinskaya, T., Hlavsa, T. \& Hruska, M. (2019). Estimation of technical efficiency of Czech farms operating in less favoured areas. Agricultural Economics 65(10), 445-453. DOI: 10.17221/52/2019-AGRICECON.

[49] Ruggiero, J. (2007). A comparison of DEA and the stochastic frontier model using panel data. International Transactions in Operational Research 14(3), 259-266. DOI: 10.1111/j.1475-3995.2007.00585.x.

[50] Shucksmith, M., Thomson, K. J. \& Roberts, D. (2005). The CAP and the regions: the territorial impact of the Common Agricultural Policy. Wallingford: CAB Int. Publishing. DOI: $10.1079 / 9780851990552.0000$. 
[51] Stanciu, S. (2017). A comparative study regarding the European agricultural allocation of funds for rural development during 2007-2013 and 2014-2020. SEA-Practical Application of Science 13, 49-55.

[52] Swinbank, A. (2008). Potential WTO Challenges to the CAP. Canadian Journal of Agricultural Economics / Revue Canadienne d'Agroeconomie 56(4), 445-456. DOI: 10.1111/j.17447976.2008.00140.x.

[53] Turnock, D. (2016). Aspects of independent Romania's economic history with particular reference to transition for EU accession. New York: Routledge. DOI: $10.4324 / 9781315568089$.

[54] Vasile, A. J., Mihai, M. \& Mirela, P. (2017). Transformations of the Romanian agricultural paradigm under domestic economic policy reforms: an analysis during 1960-2011. Land Use Policy 67, 288-297. DOI: 10.1016/j.landusepol.2017.06.008.

[55] Von Witzke, H. \& Noleppa, S. (2007). Agricultural and trade policy reform and inequality: the distribution effects of the direct payments to German farmers under the EU's new common agricultural policy [Working paper]. Berlin: Humboldt-Universität zu Berlin.

[56] Wang, H. J. \& Schmidt, P. (2002). One-step and two-step estimation of the effects of exogenous variables on technical efficiency levels. Journal of Productivity Analysis 18(2), 129-144. DOI: 10.1023/A:1016565719882.

[57] Zhu, X. \& Lansink, A. O. (2010). Impact of CAP subsidies on technical efficiency of crop farms in Germany, the Netherlands and Sweden. Journal of Agricultural Economics, 61(3), 545-564. DOI: 10.1111/j.1477-9552.2010.00254.x.

[58] Zhu, X. \& Milán Demeter, R. (2012). Technical efficiency and productivity differentials of dairy farms in three EU countries: the role of CAP subsidies. Agricultural Economics Review 13(1), 66-92. DOI: 10.22004/ag.econ.253496. 